SciDioc

International Journal of Dentistry and Oral Science (IJDOS)

ISSN: 2377-8075

\title{
Evaluation Of Facial Esthetics using Golden Proportion Values In Dravidian Population For Different Classes Of Malocclusions
}

Research Article

Prasanna Arvind T.R ${ }^{1}$, Navaneethan Ramasamy ${ }^{2 *}$, Sri Rengalakshmi ${ }^{3}$

${ }^{1}$ Department of Orthodontics, Saveetha Dental College and Hospitals, Saveetha Institute of Medical and Technical Sciences(SIMATS), Saveetha University, Chennai 600 077, Tamil Nadu, India.

${ }^{2}$ Reader, Department of Orthodontics, Saveetha Dental College and Hospitals, Saveetha Institute of Medical and Technical Sciences(SIMATS), Saveetha University, Chennai 600 077, Tamil Nadu, India.

${ }^{3}$ Senior Lecturer, Department of Orthodontics, Saveetha Dental College ad Hospitals, Saveetha institute of medical and technical sciences, Saveetha University162, Poonamallee High Road, Chennai- 600077, Tamil Nadu, India.

\section{Abstract}

\begin{abstract}
Introduction: The improvement of a patient's facial appearance is one of the main goals of contemporary orthodontic treatment. The aim of this study was to evaluate the difference in facial proportions between skeletal classes I, II, III populations in order to establish objective departures from Golden Proportion norms.

Materials And Methodology: The study sample was divided into three groups based on the skeletal malocclusion namely skeletal class I, class II and class III groups. Numerous parameters were recorded on these photographs, in order to establish facial symmetry and correlation with the ideal set of proportions. Golden Proportion values were compared with that of the obtained results and these values were checked for skeletal class I, II, III malocclusions.

Results: Our study showed significant difference between skeletal class II and III malocclusions when correlated with Golden Proportion values. Skeletal class I malocclusions showed greater correlation with golden proportion values.

Conclusions: Golden proportion ratios are more valid in cases of skeletal class I malocclusions. Hence, the objective of treating class II and class III malocclusions should be more focussed on attaining values closer to the desired ratio for optimal facial balance and symmetry.
\end{abstract}

Keywords: Golden Proportion Values; Facial Symmetry; Anthropometry; Malocclusion.

\section{Introduction}

The demand for elective procedures solely for improving esthetics is evergrowing. As a result, Orthodontists should have a good understanding of qualitative, quantitative, objective facial features which are considered as attractive and beautiful [31]. One of the main requirements for better esthetics is the balance between the proportions between the various structures of the face. Many linear and angular measures of soft tissue profile and different cephalometric analysis have been developed to determine ideal proportions [1]. The most common reason for seeking orthodontic treatment is enhancement of facial beauty through orthodontic and orthognathic procedures [27]. Unlike the 1980s, when $25 \%$ of patients required orthodontic treatment for esthetic reasons, today that percentage has risen to $75 \%$, which means that 3 out of 4 patients request an improvement of facial appearance [4].

Beauty is not an exact science but according to some plastic surgeons there is a specific proportion system that includes facial height, width and symmetry [21]. However, the definition of an attractive and beautiful face is subjective, with many included features- social, cultural, ethnic and age [5]. The beauty of the person's face is determined by the harmony of proportions and symmetry. Ideal proportions are directly related to these proportions and is explained by a ratio 1:1.618 [23].

The knowledge of divine proportion exists since ancient Greek

*Corresponding Author:

Dr. Navaneethan Ramasamy,

Reader, Department of Orthodontics, Saveetha Dental College and Hospitals, Saveetha Institute of Medical and Technical Sciences(SIMATS), Saveetha University, Chennai 600 077, Tamil Nadu, India.

Tel: +919962787531

E-mail: ethan.nava@gmail.com

Received: September 03, 2020

Accepted: September 29, 2020

Published: September 30, 2020

Citation: Prasanna Arvind T.R, Navaneethan Ramasamy, Sri Rengalakshmi. Evaluation Of Facial Esthetics using Golden Proportion Values In Dravidian Population For Different Classes Of Malocclusions. Int J Dentistry Oral Sci. 2020;S2:02:0015:70-73. doi: http://dx.doi.org/10.19070/2377-8075-SI02-020015

Copyright: Navaneethan Ramasamy ${ }^{\circ} 2020$. This is an open-access article distributed under the terms of the Creative Commons Attribution License, which permits unrestricted use, distribution and reproduction in any medium, provided the original author and source are credited. 
sculptor Phidias and it was first scientifically described by FilusBonacci, the discoverer of the numerical value of the divine proportions [15, 25]. More relevant to the dental profession as well as the medical profession are divine proportions of the human face [20]. This particularly applies to the orthodontic treatment, given that the objectives to be achieved at the end of treatment include esthetic harmony along with functional stability [24].

The aim of our study was compare the facial proportions between the three different sagittal skeletal patterns and to estimate the deviation of these values from that of the golden proportions.

\section{Materials And Methodology}

The sample consists of frontal photographs of 60 individuals. The sample was divided into three groups of 20 each based on their skeletal classification as : skeletal class I, II, III. It was a retrospective study conducted in the Department of Orthodontics at Saveetha Dental College, Chennai.

The facial photographs were taken in natural head position (NHP) using Canon Central Power Shot G6, 7.1 MP, with the same distance of $1.2 \mathrm{~mm}$. After training and calibration, all measurements on photographs were performed (Fig 1). In order to test the feasibility and reproducibility of the measurements, 12 photographs were selected and reassessed by the same author after 2 weeks.

The soft tissue points used for obtaining linear distances were measured. In the photographs, the following parameters were measured:

1) Length of the face:

- Tr-Me= height of face

- Distance between bizygomatic points= width of face

- Me-Sto $=$ lowest point on chin and point where upper and lower lip merge

- Sto-LC= point where the upper and lower lip merge and corner of the eye

- Me-Ln= Lowest point on chin and outer edge of nostril

- $\mathrm{Ln}-\mathrm{Tr}=$ outer edge of nostril and highest point of the forehead

2) Division of the face:

Horizontal thirds of the face a) upper third ( $\mathrm{Tr}-\mathrm{Gl})$

b) middle third (Gl- SubN)

c) lower third (SubN- Me)

3) Ideal proportions of the face:

The ratio of the width of face to the height of face is supposed to be $1: 1.618$

The ratio of Sto-Me: Me-Lc is supposed to be 1:1.618

The ratio Me-Ln: $\mathrm{Ln}-\mathrm{Tr}$ is supposed to be 1:1.618

\section{Statistical Analysis}

Statistical tests were performed using SPSS software Version 20.0 (SPSS Inc, Chicago). For analyzing the similarity of vertical thirds and horizontal fifths of the face, in each group, one-way ANOVA was applied and in cases where ANOVA showed statistically significant, difference between parameters- post-Hoc Tukey's HSD test for multiple comparisons was applied. In all analysis, the significance level was set at 0.05 .

\section{Results and Discussion}

The Kappa coefficient ranged from 0.715 to 0.9 which rated the reliability of the test results to be from good to fairly good in agreement. In Table 1, ANOVA test of variance was used to determine variations in ratio between width to height of face in three skeletal malocclusions. Skeletal class I and III groups showed significant differences. But significant variations in Golden Proportion values were seen in Skeletal class II and III groups.

In Table II, ANOVA test of variance was used to determine variations in ratio between Sto-Me:Sto-LC in three skeletal malocclusions. Skeletal class I and III groups were statistically significant. Skeletal class II and III groups were also statistically significant. Variations from Golden Proportion Values were seen in Class II and Class III groups. Differences in values from Golden Proportion Values were seen in Class II and Class III groups. It is not consistently seen in most features of Class II, III patients in Dravidian Population.

This study was done to evaluate the differences in facial proportions between skeletal class I, II, III malocclusions. Comprehension and analysis of facial parameters are necessary in different

Figure 1. Determination of facial characteristics done with the following identification marks (soft tissue points) in MSWord for calibration of distances in $\mathrm{mm}$.

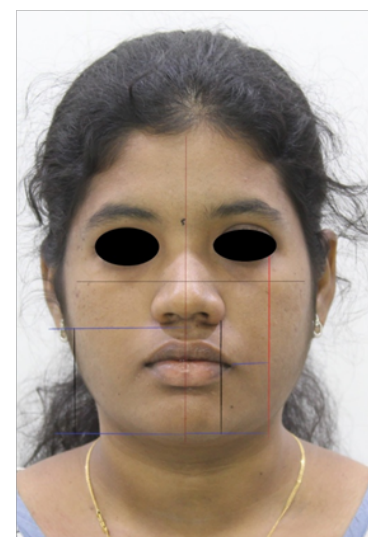


Table 1. ANOVA Test of Variance for ratio between width to height of face.

\begin{tabular}{|c|c|c|c|c|}
\hline & N & Mean & S.D. & Sig. \\
\hline Skeletal class I & 20 & 1.62 & 0.02 & 0.89 \\
\hline Skeletal class II & 20 & 1.66 & 0.3 & 0.6 \\
\hline Skeletal class III & 20 & 1.74 & 0.38 & 0.34 \\
\hline
\end{tabular}

Table 2. ANOVA Test of Variance for ratio between Sto-Me to Sto-LC.

\begin{tabular}{|c|c|c|c|c|}
\hline & N & Mean & S.D. & Sig. \\
\hline Skeletal class I & 20 & 1.63 & 0.07 & 0.93 \\
\hline Skeletal class II & 20 & 1.64 & 0.16 & 0 \\
\hline Skeletal class III & 20 & 1.51 & 0.12 & 0.01 \\
\hline
\end{tabular}

fields of medicine and dentistry especially among specialists like plastic surgeons, maxillofacial surgeons, orthodontists and prosthodontists [29].

Keeping that in mind, there is a need for clinicians who work in a maxillofacial region to understand and become familiar with guidelines for esthetic standards and parameters of soft tissues [13]. Our study results were similar to Bashour et al who stated skeletal class I malocclusions to be more in correlation with Golden Proportion. Bashour et al stated that there are four most important tips for determining effectiveness: averageness, sexual dimorphism, youthfulness and symmetry [26]. A surgeon who is planning for facial cosmetic, plastic or reconstructive surgery can potentially gain both profound comprehension and better quality surgical results by appreciating these findings [17].

Division of the face into thirds and fifths is a commonly used photogrammetric method for assessing facial symmetry. In our study, all of these measures were uniform in the group selected and we selected measurements that could be reproduced by different operators [30]. Several 'neonatal' characteristics, such as relatively large forehead and a rounded and smaller face in general, stated that 'babyness' is the characteristic that separates them from the normal group. Considering a majority of parameters of the face, more correlated phases had a smaller face [5]. Mack was the first to demonstrate the practical applications of ideal proportions for improving facial esthetics [8]. He discussed the importance of treating the dentition to the face based on the divine proportion. According to him, the lower $1 / 3$ rd of the face significantly influences facial appearance [10]. As proof, he stresses the public's preoccupation with fullness of the lips and the importance of a pleasing smile [22]. These so-called Vitruvian Thirds in the lower face have to be adjusted to a 30\% upper lip, $70 \%$ lower lip-chin projection [18]. In our study, attractive groups (Class I) showed harmonized lower third of the face, with lower facial index (subnasale-stomion, stomion-menton) in accordance with the beauty cannon [11]. Therefore, this ideal ratio should be suitable in the planning concept for treatment in the facial region. These distances and divisions in the lower-third of the face are one of the most important in the evaluation of facial beauty, given the fact that the lips and the chin highly determine female beauty [19]. Ferrario et al reported that attractive women share similar facial characteristics such as increased upper facial third, smaller face and more voluminous lips than non-attractive ones [7]. In addition, it was stressed that the length of the nose was therefore smaller on the skeletal class I group [16]. In the study by Hall et al, it was shown that thickness of the lips was one of the main features in the beauty perception based on a poll among orthodontists and the general public [9]. In some cases, standard camera distortions in cinema images made certain female faces appear more beautiful because they are overall 'shortened' [17]. In our study, the values for vertical length parameters such as distance between points Me-ch and ch-LC as well as Me-LN and LN-Tr which should be in relation determined by ideal proportions, differed in the group of skeletal class II, III malocclusions [14]. Therefore, faces of skeletal class I proportions are closer to the ideal proportions [3].

Torsella et al found that some of the neoclassical canons can be considered still valid, while others seem to be updating [2]. According to their research, it seems that reductions in facial middle-third, in distance between eyes and in nose dimensions have occurred as well as relative enlargement of eyes and mouth width [28]. These guidelines considering facial beauty can be used for improving patients facial appearance [6]. Clinicians must be aware that each and every person has their own beauty perception, so these results should be viewed with caution [12].

\section{Conclusion}

Facial beauty and determinants are one of the more arguable topics among surgeons, dentists and orthodontists. Skeletal class I malocclusions are closer to Golden Proportion ratios. Significant difference seen between Golden Proportion values and Class II, III malocclusions.

\section{References}

[1]. Ayub FB, Agarwal A, Kumar RR. The Propinquity of Golden Proportion in Orthodontics. Journal of Orofacial\& Health Sciences. 2019;10(1):7-12.

[2]. Dinesh SP, Arun AV, Sundari KK, Samantha C, Ambika K. An indigenously designed apparatus for measuring orthodontic force. J ClinDiagn Res. 2013 Nov;7(11):2623-6. PubmedPMID: 24392423.

[3]. Felicita AS, Chandrasekar S, Shanthasundari KK. Determination of craniofacial relation among the subethnic Indian population: a modified approach - (Sagittal relation). Indian J Dent Res. 2012 May-Jun;23(3):305-12. PubmedPMID: 23059564.

[4]. Felicita AS. Orthodontic management of a dilacerated central incisor and partially impacted canine with unilateral extraction - A case report. Saudi Dent J. 2017 Oct;29(4):185-193. PubmedPMID: 29033530.

[5]. Felicita AS. Quantification of intrusive/retraction force and moment generated during en-masse retraction of maxillary anterior teeth using mini-implants: A conceptual approach. Dental Press J Orthod. 2017 Sep-Oct;22(5):47-55. 
PubmedPMID: 29160344.

[6]. Felicita AS. Orthodontic extrusion of Ellis Class VIII fracture of maxillary lateral incisor - The sling shot method. Saudi Dent J. 2018 Jul;30(3):265-269. PubmedPMID: 29942113.

[7]. Ferrario VF, Sforza C, Miani A Jr, Tartaglia G. Mathematical definition of the shape of dental arches in human permanent healthy dentitions. Eur J Orthod. 1994 Aug;16(4):287-94.pubmed PMID: 7957653.

[8]. Bernhardt O, Gesch D, Schwahn C, Mack F, Meyer G, John U, Kocher T. Epidemiological evaluation of the multifactorial aetiology of abfractions. J Oral Rehabil. 2006 Jan;33(1):17-25.

[9]. Hobson RS, Carter NE, Hall FM, Atkins MJ. A study into the effectiveness of a text-based computer-assisted learning program in comparison with seminar teaching of orthodontics. European Journal of Dental Education. 1998 Nov;2(4):154-9.

[10]. Jahanbin A, Basafa M, Alizadeh Y. Evaluation of the Divine Proportion in the facial profile of young females. Indian J Dent Res. 2008 Oct-Dec;19(4):292-6. PubmedPMID: 19075430.

[11]. Jain RK, Kumar SP, Manjula WS. Comparison of intrusion effects on maxillary incisors among mini implant anchorage, $j$-hook headgear and utility arch. J ClinDiagn Res. 2014 Jul;8(7):ZC21-4. PubmedPMID: 25177631.

[12]. Jebaraj S, Dhanraj M, Jain AR. Prevalence of different crown forms of central incisor among South Indian population. Drug Invention Today. 2018 Sep $1 ; 10(9)$.

[13]. Kamisetty SK, Verma JK, Arun, Sundari S, Chandrasekhar S, Kumar A. SBS vsInhouse Recycling Methods-An Invitro Evaluation. J ClinDiagn Res. 2015 Sep;9(9):ZC04-8. PubmedPMID: 26501002.

[14]. Katona TR, Paydar NH, Akay HU, Roberts WE. Stress analysis of bone modeling response to rat molar orthodontics. J Biomech. 1995 Jan;28(1):27-38. PubmedPMID: 7852439

[15]. Krishnan S, Pandian S, Kumar S A. Effect of bisphosphonates on orthodontic tooth movement-an update. J ClinDiagn Res. 2015 Apr;9(4):ZE01-5. PubmedPMID: 26023659.

[16]. Ramesh Kumar KR, ShantaSundari KK, Venkatesan A, Chandrasekar S. Depth of resin penetration into enamel with 3 types of enamel conditioning methods: a confocal microscopic study. Am J OrthodDentofacialOrthop. 2011 Oct;140(4):479-85. PubmedPMID: 21967934.

[17]. Mantelakis A, Iosifidis M, Al-Bitar ZB, Antoniadis V, Wertheim D, Garagiola U, Naini FB. Proportions of the aesthetic African-Caribbean face: idealized ratios, comparison with the golden proportion and perceptions of attractiveness. MaxillofacPlastReconstr Surg. 2018 Sep 5;40(1):20. PubmedPMID: 30206536 .

[18]. Naini FB, Moss JP, Gill DS. The enigma of facial beauty: esthetics, proportions, deformity, and controversy. Am J OrthodDentofacialOrthop. 2006
Sep;130(3):277-82. PubmedPMID: 16979484

[19]. Pandian KS, Krishnan S, Kumar SA. Angular photogrammetric analysis of the soft-tissue facial profile of Indian adults. Indian J Dent Res. $2018 \mathrm{Mar}-$ Apr;29(2):137-143. PubmedPMID: 29652003.

[20]. Pini NP, de-Marchi LM, Gribel BF, Ubaldini AL, Pascotto RC. Analysis of the golden proportion and width/height ratios of maxillary anterior dentition in patients with lateral incisor agenesis. J EsthetRestor Dent. 2012 Dec;24(6):402-14. PubmedPMID: 23205688.

[21]. Rossetti A, De Menezes M, Rosati R, Ferrario VF, Sforza C. The role of the golden proportion in the evaluation of facial esthetics. Angle Orthod. 2013 Sep;83(5):801-8. PubmedPMID: 23477386

[22]. Rubika J, SumathiFelicita A, Sivambiga V. Gonial angle as an indicator for the prediction of growth pattern. World Journal of Dentistry. 2015;6(3):161-3

[23]. Sabrish S, Shetty K, Nandini S, et al. (2013) Are all mandibles golden? A cephalometric study of mandibular morphology as compared to the golden proportion. APOS Trends in Orthodontics. DOI: 10.4103/2321-1407.115982.

[24]. Saifuddeen SM, Masran MR. Fibonacci Sequence and orderliness as observed in the creations of Allah. Online Journal of Research in Islamic Studies. 2017 Dec 21;1(1):103-22.

[25]. Samantha C, Sundari S, Chandrasekhar S, Sivamurty G, Dinesh S. Comparative Evaluation of Two Bis-GMA Based Orthodontic Bonding Adhesives - A Randomized Clinical Trial. J ClinDiagn Res. 2017 Apr;11(4):ZC40-ZC44. PubmedPMID: 28571259.

[26]. Sforza C, Laino A, D'Alessio R, Grandi G, Tartaglia GM, Ferrario VF. Softtissue facial characteristics of attractive and normal adolescent boys and girls. Angle Orthod. 2008 Sep;78(5):799-807. PubmedPMID: 18298221.

[27]. Sivamurthy G, Sundari S. Stress distribution patterns at mini-implant site during retraction and intrusion--a three-dimensional finite element study. ProgOrthod. 2016;17:4. PubmedPMID: 26780464.

[28]. Sugumaran S, Pandian S. Golden proportion of the mandible in differen classes of skeletal malocclusions-A pilot study. Drug Invention Today. 2019 Jan $1 ; 11(1)$.

[29]. Vikram NR, Prabhakar R, Kumar SA, Karthikeyan MK, Saravanan R. Ball Headed Mini Implant. J ClinDiagn Res. 2017 Jan;11(1):ZL02-ZL03. PubmedPMID: 28274084

[30]. Viswanath A, Ramamurthy J, Dinesh SP, Srinivas A. Obstructive sleep apnea: awakening the hidden truth. Niger J ClinPract. 2015 Jan-Feb;18(1):1-7. PubmedPMID: 25511335.

[31]. Young TM, Smith RJ. Effects of orthodontics on the facial profile: a comparison of changes during nonextraction and four premolar extraction treatment Am J OrthodDentofacialOrthop. 1993 May;103(5):452-8. PubmedPMID: 8480714 